J. Appl. Glycosci., 51, 81-85 (2004)

(C) 2004 The Japanese Society of Applied Glycoscience

\title{
Diurnal-Nocturnal Changes of Assimilated Starch Structures in Sweetpotato Leaves
}

\author{
(Received August 19, 2003 ; Accepted November 12, 2003)
}

\author{
Kanefumi Kitahara, ${ }^{*}$ Takayuki Uchino, Ichiyo Okizono and Toshihiko Suganuma \\ Department of Biochemical Science and Technology, Faculty of Agriculture, Kagoshima University \\ (1-21-24, Korimoto, Kagoshima 890-0065, Japan)
}

\begin{abstract}
Sweetpotato leaves cultivated for three months were harvested at different times for two days, and starch structures in the leaves were examined. The starch content changed in a circadian rhythm, with the minimum at 05:00 and the maximum at 17:00. The starches in the leaves were extracted by maceration of the leaf debris in hot dimethyl sulfoxide and prepared by selective precipitation by iodine. Gel-permeation chromatography of the leaf starches and amylopectins on Toyopearl HW-75F revealed that the leaf starches had a higher amount of material eluted at a low molecular weight fraction compared to that of its root starch, and the low molecular weight fraction contained both amylose molecules and a large amount of small amylopectin molecules. It was also found that both molecular weight distributions of the leaf starch and amylopectin were shifted to high molecular weight during the daytime and to low molecular weight during the period from sunset to sunrise. After debranching the starches and amylopectins, the chain-length distributions and short-chain distributions were analyzed by high-performance gel-permeation chromatography and high-performance anion-exchange chromatography, respectively. The chain-length distributions of the leaf starches were clearly distinct from those of the root starch. The amylose content of the leaf starches, which was evaluated as the difference in long-chain fraction on chain-length distribution between starch and amylopectin, was low during the daytime, whereas the branch aspect of the leaf amylopectin was relatively constant throughout the whole day. Thus, the structural characteristics of the starch in sweetpotato leaf and their diurnal-nocturnal changes have been revealed.
\end{abstract}

Key words: leaf starch, sweetpotato, amylose, amylopectin

Higher plants generally synthesize starches in both photosynthetic tissues of leaves and storage organs such as seed or root, and the starches often refer to assimilated (or transitory) starch and reserved (or storage) starch, respectively. Since the storage organs have a significant role in agronomy and human nutrition as food, there have been extensive studies on the chemical structural aspects of their starches, but fewer on starches in leaves.

Among studies on leaf starches, starches from tobacco and cotton leaves have been relatively well examined. It was reported that the starch content in tobacco leaves increased during the daytime, and the amylose content was lower during the daytime than at night. ${ }^{1,2}$ For cotton plants grown in a chamber, it was observed that the starch content increased accompanied by a preferential accumulation of amylopectin during the light period. ${ }^{3)}$ Furthermore, Matheson ${ }^{4}$ investigated the molecular structures of tobacco leaf starch in detail as follows: firstly the amylose content, ranging from 15.7 to $17.2 \%$, was low during the daytime; secondly the amylose fractions had small differences in average molecular size at different times, whereas the average molecular size of amylopectin decreased during the daytime and increased at night; and finally the chain-length distribution of amylopectin was similar throughout the whole day. On the other hand, it has been reported that the leaf starches from $\mathrm{pea}^{5)}$ and

* Corresponding author (Tel.+81-99-285-8638, Fax. +81-99285-8639, E-mail: kitahara@chem.agri.kagoshima-u.ac.jp)
Arabidopsis $^{6}$ contain amylopectin almost exclusively. Thus, it seems that the structural aspects of leaf starches are diverse among the respective plant species and more dynamic than those of starches from storage organs. Since the studies on starch structures in leaves have been limited to a few species, further investigations of leaf starches are required.

In this paper, we describe structural differences between starches from the leaf and tuberous root of the sweetpotato. The leaf starches and their amylopectins were prepared from leaves harvested at different times, and the diurnal-nocturnal changes in structure were examined in terms of both molecular weight distribution and chainlength distribution.

\section{MATERIALS AND METHODS}

Materials. Fifty seedlings of sweetpotato (Ipomoea batatas, cv. Koganesengan) were planted in an experimental field of Kagoshima University in June 2002. After cultivation for three months, five leaves with similar sizes (13 cm in length) were detached randomly from the middle of the runner of the independent plants at different times over two days. The leaves were immediately frozen in liquid nitrogen and lyophilized. The tuberous roots were cropped at the end of October.

All reagents and solvents, unless otherwise specified, were obtained from Wako Pure Chemical Industries (Japan) and were of analytical grade. Water was treated by 
passing it through a Milli-Q Labo (Nihon Millipore Ltd., Japan) prior to use.

Preparation of starch and amylopectin. The starch content of the lyophilized leaf was measured as a glucoamylase-digestible polysaccharide, as previously reported. ${ }^{7)}$

Starch granules were prepared from the tuberous root according to our previous reports. $\left.{ }^{8}\right)$ Leaf starch was prepared using a procedure reported by Matheson" with our modification. The five lyophilized leaves were ground using a MILLSER IFM-750G (Iwatani Ltd., Japan). The powdered leaf $(1 \mathrm{~g})$ was immersed in acetone $(50 \mathrm{~mL})$ and decolorized overnight. The leaf debris was softened in dimethyl sulfoxide $(50 \mathrm{~mL})$ at $100^{\circ} \mathrm{C}$ for 30 min under bubbling nitrogen gas and macerated in a glass homogenizer (Iwaki, Japan). The extract was collected by centrifugation $(2800 \times g, 10 \mathrm{~min})$, while the residual debris was re-extracted with dimethyl sulfoxide by the homogenizer. The combined extract was poured into ethanol (300 $\mathrm{mL}$ ) with a slight amount of lithium chloride and left to stand overnight. The precipitate was collected by centrifugation. The crude starch was extracted from the precipitate with $1 \mathrm{M}$ sodium chloride $(25 \mathrm{~mL})$ at $100^{\circ} \mathrm{C}$ for 30 min under bubbling nitrogen gas, and the extraction was repeated twice. After centrifugation, an excessive amount of iodine (3\% iodine in $30 \%$ potassium iodide solution, 2 $\mathrm{mL}$ ) was added to the supernatant, which was left to stand overnight. The starch-iodine precipitate was dissolved in a solution of $0.1 \mathrm{M}$ sodium arsenite in $0.2 \mathrm{M}$ sodium phosphate buffer ( $\mathrm{pH} 6.0,20 \mathrm{~mL}$ ), and then the solution was dialyzed against water. The dialyzate was poured into ethanol $(80 \mathrm{~mL})$ with a slight amount of lithium chloride and left to stand overnight. After centrifugation, the precipitate was washed with ethanol repeatedly and dried in a vacuum desiccator.

Amylopectin was prepared from a supernatant after the removal of amylose by butanol complexing. ${ }^{10)}$

Molecular weight distribution of starch and amylopectin. The defatted $\operatorname{starch}^{8)}$ or amylopectin $(10 \mathrm{mg})$ was dissolved in $1 \mathrm{M}$ sodium hydroxide $(5 \mathrm{~mL})$ at $4^{\circ} \mathrm{C}$. The solution was diluted twice with water and an aliquot (2 $\mathrm{mL})$ was applied to a column $(1.3 \times 48 \mathrm{~cm})$ packed with Toyopearl HW-75F (Tosoh Corporation, Japan). The column was eluted with $0.2 \%$ sodium chloride in $50 \mathrm{~mm}$ sodium hydroxide at a flow rate of $60 \mathrm{~mL} / \mathrm{h}$. Each eluate $(2$ $\mathrm{mL})$ was neutralized with $1 \mathrm{M}$ acetic acid $(0.3 \mathrm{~mL})$, and the total carbohydrate content of an aliquot $(1 \mathrm{~mL})$ was determined by measuring the glucose according to the phenol-sulfuric acid method. ${ }^{11)}$ On the other hand, $1 \%$ iodine in $10 \%$ potassium iodide solution $(20 \mu \mathrm{L})$ was added to the remaining eluate $(1.3 \mathrm{~mL})$, and the wavelength at maximum absorption of the starch-iodine complex $\left(\lambda_{\max }\right)$ was measured in the range of 400-700 nm using a spectrophotometer (U-3310, Hitachi, Japan).

Chain-length distribution of debranched starch and amylopectin. After debranching starch or amylopectin by isoamylase (Nacalai Tesque Inc., Japan), the chainlength distribution of the debranched sample was determined by both high-performance gel-permeation chromatography $^{12)}$ (GPC) using two linked columns of Superose 6 and Sephadex G25SF (Amersham Bioscience K.K., Japan) and high-performance anion-exchange chromatography ${ }^{7)}$ (HPAEC) using a CarboPac PA-1 column (Nippon Dionex K.K., Japan).

\section{RESULTS AND DISCUSSION}

\section{Change in starch content in sweetpotato leaves.}

The sweetpotato leaves were harvested at 05:00 (before dawn), 09:00, 13:00, 17:00, 20:00 (after dusk) and 00:00 over two days. Figure 1 shows the change in starch content of the lyophilized leaves at different times. The starch content was the minimum at 05:00 and the maximum at 17:00 on both days, and the minimum content amounted to $7 \%$ at $05: 00$, which indicated that the starches do not disappear completely during night period. The diurnalnocturnal change in the starch content of sweetpotato leaves was similar to the result obtained for tobacco leaves. ${ }^{1)}$ It was also reported that the starch remaining in leaves at night was different depending on leaf age ${ }^{1)}$ and leaf position. ${ }^{13)}$ Thus, a circadian rhythm of starch content was observed in sweetpotato leaves.

\section{Starch preparation.}

Previously we carried out starch extraction from leaves of a wild sweetpotato relative simply by macerating the leaves, and it was easy and successful. ${ }^{7)}$ However, the application in this study for leaves of sweetpotato cultivar was unsuccessful, resulting in a low starch yield of less than $10 \%$. A microscopic observation of the residues after starch extraction revealed that the starches were still trapped in the cells. It seems that the leaves of sweetpotato cultivars have a strong cell wall, which causes difficulty in starch extraction by simple maceration. Therefore, the starches in the leaves were extracted by maceration of the leaf debris in hot dimethyl sulfoxide and prepared by selective precipitation by iodine. To check damage to the starch structure by the extraction process, starch granules from the tuberous root were treated using the same procedure as for leaf starch extraction. Both molecular weight distributions and chain-length distributions after debranching were practically identical before and after treatment (data not shown), demonstrating a negligible, if any, degradation of starch molecules during the process. Consequently, the starches were extracted from the leaf samples harvested at different times of the first day, which yielded $60-85 \%$ of the respective starch contents.

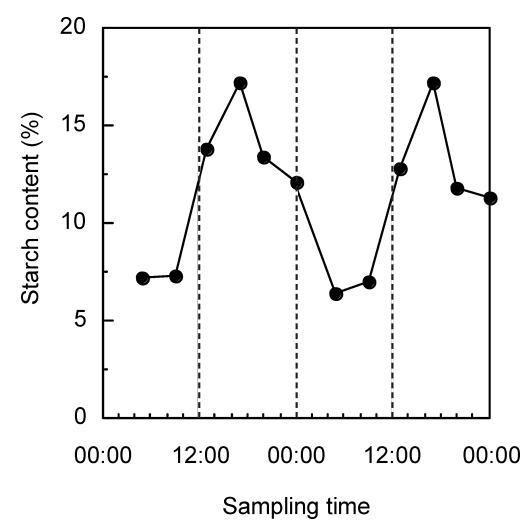

Fig. 1. Diurnal-nocturnal change in starch content in sweetpotato leaves over two days. 


\section{Molecular weight distribution.}

Figure 2 shows the molecular weight distributions of the root starch and its amylopectin on a Toyopearl HW$75 \mathrm{~F}$ column, as well as the $\lambda_{\max }$ of starch-iodine coloration in each fraction. The distribution of root starch showed a typical elution profile having a large amount of high molecular weight fraction and a small amount of low molecular weight fraction. The high and low molecular weight fractions have been shown to mainly correspond to amylopectin and amylose, respectively. ${ }^{14}$ As shown in Fig. 2B, the root amylopectin was eluted almost at the high molecular weight fraction.

The elution profiles of the leaf starches were quite distinct from that of the root starch as seen in Fig. 3. The molecular weight distributions of the leaf starches showed a considerable amount of material eluted at the low molecular weight fraction. The material eluted at the lower molecular weight fraction had a higher $\lambda_{\max }$, suggesting the existence of long linear glucans in this region. After removing amylose by butanol complexing, the molecular weight distributions of the isolated amylopectins were also examined. The leaf amylopectins distributed themselves over a wide range on the column, unlike the root amylopectin. The $\lambda_{\max }$ at the lower molecular weight fraction decreased because of the removal of amylose. These results suggest that the low molecular weight fraction of the leaf starches contains both amylose molecules and a large amount of small amylopectin molecules.

Diurnal-nocturnal changes in the molecular weight distributions of the starch and amylopectin were found. On the starch distributions, the amount of material eluted at the lower molecular weight fraction was high at 05:00 and 09:00. The proportion of the low molecular weight fraction decreased at 13:00 and 17:00, and then increased

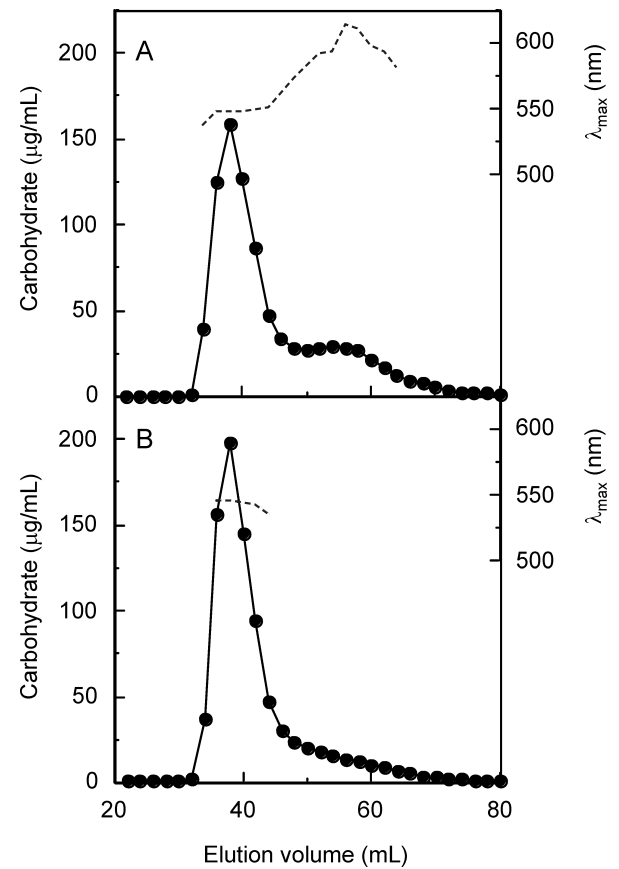

Fig. 2. Molecular weight distributions of starch and amylopectin from sweetpotato root by GPC on Toyopearl HW-75F.

(A) starch, (B) amylopectin. Solid line with closed circles indicates carbohydrates, and dotted line indicates the $\lambda_{\max }$ in each eluate. at 20:00 and 00:00. The diurnal-nocturnal change in the molecular weight distribution of amylopectin showed a similar tendency to that of the starches. The distribution of amylopectin was shifted to high molecular weight during the daytime and shifted to low molecular weight during the period from sunset to sunrise. The result indicates that the average molecular weight of amylopectin increases during the daytime. Contrary to our result, it was reported that the average molecular weight of amylopectin from young tobacco leaves decreased during illumination, where it was speculated that low molecular weight materials were preferentially depleted in darkness and preferentially accumulated on illumination. ${ }^{4)}$ The reason for this discrepancy is not clear, but since the whole molecular weight distribution would be determined by a relative balance between the creation of fresh molecules and growth of molecules during the starch synthesis, such a balance may be characteristic to the respective plant species or leaf age.

\section{Chain-length distribution.}

After debranching the starches and amylopectins with isoamylase, the chain-length distributions and short-chain distributions were determined by GPC and HPAEC, respectively. Figure 4 shows the chain-length distributions on GPC and division of the chromatograms into three fractions, Frs. 1, 2 and 3. The proportion of each fraction is summarized in Table 1. The elution profiles in Fr. 1 of the leaf starches were distinct from that of the root starch,

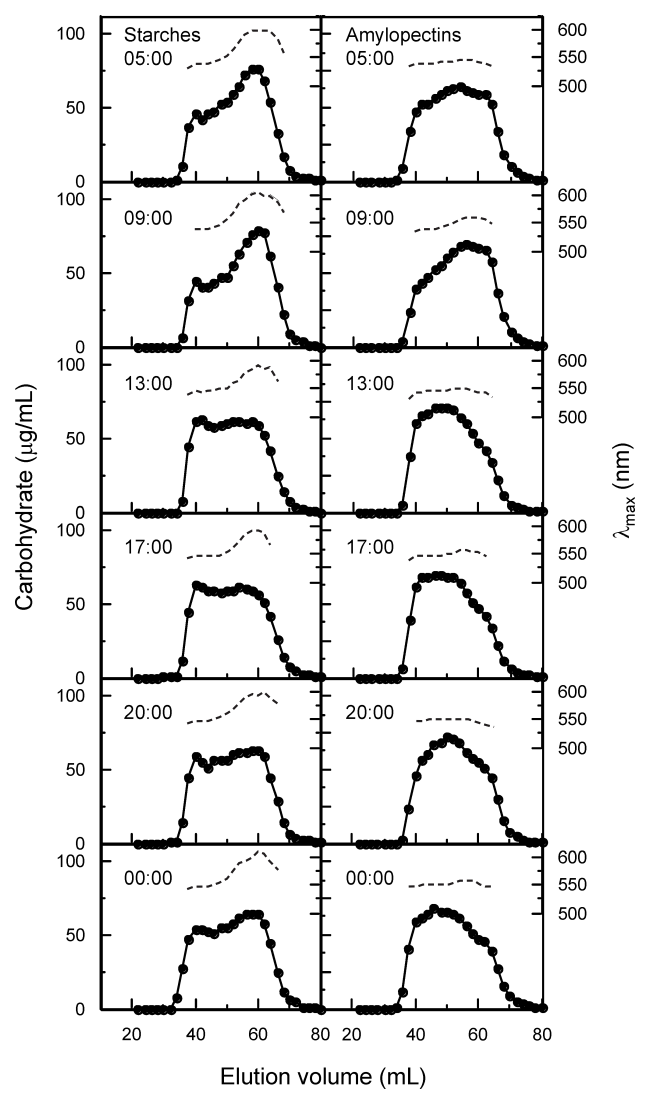

Fig. 3. Molecular weight distributions of starches and amylopectins from sweetpotato leaves at different times by GPC on Toyopearl HW-75F.

Solid line with closed circles indicates carbohydrates, and dotted line indicates the $\lambda_{\max }$ in each eluate. 
showing a lower amount of long chains eluted at void volume and a higher amount of the succeeding intermediate chains eluted at the middle of Fr. 1. A characteristic distribution was also observed in Fr. 3 of the leaf starches. As shown in Table 1, the values of Fr. 3/Fr. 2 of the leaf starches were lower than that of the root starch.

On the distribution of the root amylopectin, most of Fr. 1 disappeared, as a result of the removal of amylose molecules. When the distributions were compared be-

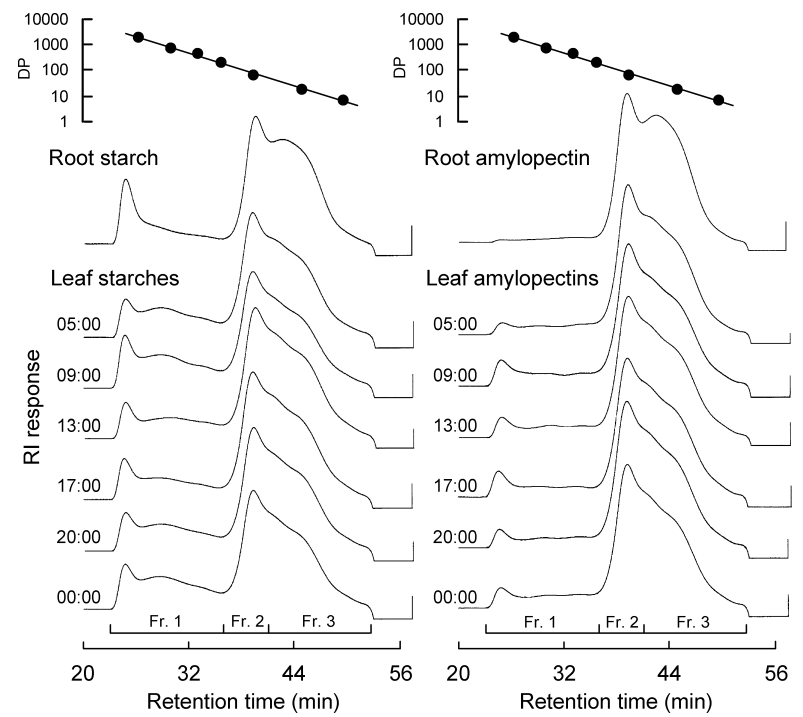

Fig. 4. Chain-length distributions of debranched starches and amylopectins from sweetpotato root and leaves at different times.

The estimated degree of polymerization (DP) from the calibration standards is shown above the elution profiles.

Table 1. Fractions of debranched starches and amylopectins from sweetpotato root and leaves at different times determined by GPC.

\begin{tabular}{lccccc}
\hline & $\begin{array}{c}\text { Fr. 1 } \\
(\%)\end{array}$ & $\begin{array}{c}\text { Fr. 2 } \\
(\%)\end{array}$ & $\begin{array}{c}\text { Fr. 3* } \\
(\%)\end{array}$ & $\begin{array}{c}\text { Fr. 3/ } \\
\text { Fr. 2 }\end{array}$ & $\begin{array}{c}\Delta \text { Fr. 1** } \\
(\%)\end{array}$ \\
\hline $\begin{array}{l}\text { Starches } \\
\text { Root }\end{array}$ & 19.6 & 30.4 & 50.0 & 1.6 & 15.7 \\
Leaves & & & & & \\
05:00 & 23.8 & 31.1 & 45.1 & 1.5 & 14.9 \\
09:00 & 28.3 & 29.8 & 41.9 & 1.4 & 14.4 \\
13:00 & 18.8 & 32.2 & 49.0 & 1.5 & 7.0 \\
17:00 & 19.8 & 31.6 & 48.6 & 1.5 & 7.4 \\
20:00 & 23.1 & 31.2 & 45.7 & 1.5 & 12.6 \\
00:00 & 27.1 & 29.9 & 43.0 & 1.4 & 14.6 \\
\hline Amylopectins & & & & & \\
Root & 3.9 & 36.5 & 59.6 & 1.6 & - \\
Leaves & & & & & \\
05:00 & 8.9 & 37.5 & 53.6 & 1.4 & - \\
09:00 & 13.9 & 36.4 & 49.7 & 1.4 & - \\
13:00 & 11.8 & 34.0 & 54.2 & 1.6 & - \\
17:00 & 12.4 & 35.1 & 52.5 & 1.5 & - \\
20:00 & 10.5 & 36.5 & 53.0 & 1.5 & - \\
00:00 & 12.5 & 37.3 & 50.2 & 1.3 & - \\
\hline
\end{tabular}

${ }^{*}$ Fractionation of each fraction is shown in Fig. $4 .{ }^{* *}$ Difference in Fr. 1 contents of the starch and amylopectin. tween the leaf starches and leaf amylopectins, a part of the chains at the void volume and most of the succeeding intermediate chains in Fr. 1 were estimated to be amylose molecules. The existence of intermediate chains of amylose was characteristic of the leaf starches, which indicated that the leaf amylose has a lower average molecular weight than the root amylose. The amylose content of the starches was therefore evaluated as a difference in the respective amounts of Fr. 1 between the starch and amylopectin. As shown as $\Delta$ Fr. 1 in Table 1 , the leaf starches of sweetpotato had amylose to some extent, although it was reported that leaf starches of pea ${ }^{5)}$ and Arabidopsis ${ }^{6}$ contain amylopectin exclusively. The amounts of amylose were lower during the daytime than at night, which was consistent with the results from tobacco leaves ${ }^{1,2,4)}$ and cotton leaves. ${ }^{3)}$ Since a selective degradation of amylose molecules is unlikely when the starch content is increasing during the daytime, it is considered that amylopectin molecules are preferentially synthesized during the daytime.

On the other hand, it is known that amylopectins from some reserved starches such as rice and maize ${ }^{15)}$ as well as sweetpotato $^{8,16)}$ have amylose-like long chains. There were also observed the long chains eluting in Fr. 1 from the leaf amylopectins, and the amounts were rather larger than that of the root amylopectin. The chain-length distribution of leaf amylopectin has been so far determined only for the tobacco leaf. ${ }^{4}$ Although the preparation method for amylopectin and the GPC conditions were different from those in this study, the tobacco leaf amylopectins also had $6 \%$ to $9 \%$ of the long chains in the molecules. Thus, the existence of the long chains in leaf amylopectins would be of interest in studying organ-specific biosynthesis of starches.

Figure 5 shows the short-chain distributions of the leaf starches with DP 6-40 at different times as compared to that of the root starch. The distributions of the leaf starches were different from that of root starch; in particular, a distinct shoulder from DP 18 was observed in the leaf starches, which was common to the leaves of pea," Arabidopsi $^{(6)}$ and a sweetpotato relative. ${ }^{7)}$ Among the leaf starches at different times, the distributions scarcely changed throughout the whole day. Thus, a diurnalnocturnal change in amylose content was found, whereas no significant difference in amylopectin structures such as Fr. 3/Fr. 2 or short-chain distribution was found in terms

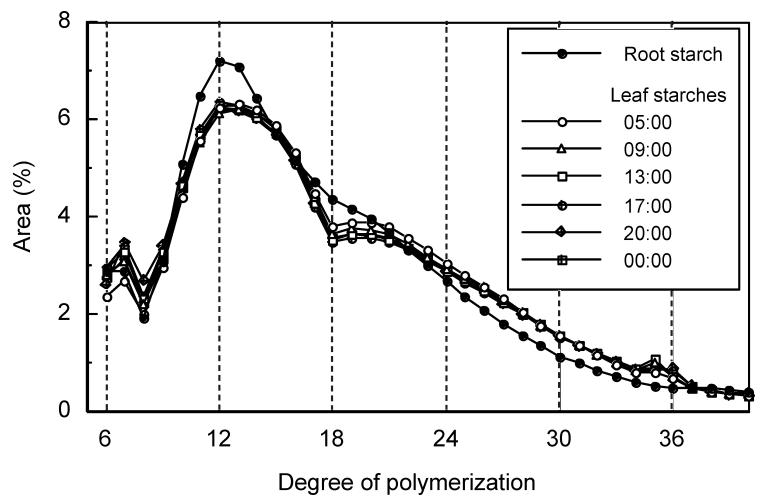

Fig. 5. Short-chain distributions of debranched starches from sweetpotato root and leaves at different times. 
of chain-length distribution.

In this study, the structural characteristics of leaf starches from sweetpotato and their diurnal-nocturnal changes have been revealed. The starch content in the leaves changed in a circadian rhythm, showing that the content increased during the daytime and decreased during the night. Analyses by GPC and HPAEC revealed that the leaf starches were composed of both amylose and amylopectin, and that the molecular weight distribution, chainlength distribution and short-chain distribution of the leaf starches were distinct from the respective distributions of the tuberous root starch. With respect to the diurnalnocturnal changes in the leaf starch structures, it was observed that the amylose content of the leaf starches decreased, and the molecular weight distribution of the leaf amylopectin was shifted to high molecular weight during the daytime, which suggests that amylopectin molecules are preferentially synthesized during the daytime. On the other hand, the branch aspect of the leaf amylopectin was relatively constant throughout the whole day. These findings would contribute to the elucidation of organ-specific biosynthesis of starches.

\section{REFERENCES}

1 ) N.K. Matheson and J.M. Wheatley: Diurnal-nocturnal changes in the starch of tobacco leaves. Aust. J. Biol. Sci., 16, 70-76 (1963).

2 ) T. Kakie and Y. Sugizaki: Diurnal changes in the starch and sugars of tobacco leaves. Soil Sci. Plant Nutr., 16, 201-203 (1970).

3 ) C.W. Chang: Starch and its component ratio in developing cotton leaves. Plant Physiol., 63, 973-977 (1979).

4 ) N.K. Matheson: The chemical structure of amylose and amylopectin fractions of starch from tobacco leaves during development and diurnally-nocturnally. Carbohydr. Res., 282, 247262 (1996)

5 ) K.L. Tomlinson, J.R. Lloyd and A.M. Smith: Importance of isoforms of starch-branching enzyme in determining the structure of starch in pea leaves. The Plant J., 11, 31-43 (1997).

6 ) S.C. Zeeman, T. Umemoto, W.-L. Lue, P. Au-Yeung, C. Martin, A.M. Smith and J. Chen: A mutant of Arabidopsis lacking a chloroplastic isoamylase accumulates both starch and phytoglycogen. The Plant Cell, 10, 1699-1711 (1998).

7 ) K. Kitahara, K. Imamura, Y. Omae and T. Suganuma: Characterization of molecular structure of starch granules in suspension-cultured cells from Ipomoea cordatotriloba Denn. Biosci. Biotechnol. Biochem., 62, 1962-1967 (1998).

8 ) K. Kitahara, Y. Ooi, S. Mizukami, T. Suganuma and T. Nagahama: Physicochemical properties of starches from sweetpotato cultivars. J. Appl. Glycosci, 43, 59-66 (1996).

9 ) N.K. Matheson: The $\alpha(1-4)(1-6)$ glucans from sweet and normal corns. Phytochemistry, 14, 2017-2021 (1975).

10) Y. Takeda, S. Hizukuri and B.O. Juliano: Purification and structure of amylose from rice starch. Carbohydr. Res., 148, 299-308 (1986).

11) M. Dubois, K.A. Gilles, J.K. Hamilton, P.A. Rebers and F.
Smith: Colorimetric method for determination of sugars and related substances. Anal. Chem., 28, 350-356 (1956).

12) K. Kitahara, T. Suganuma and T. Nagahama: Bound free fatty acids in glucoamylase-digested starches of corn and sweetpotato. Cereal Chem., 71, 439-443 (1994).

13) C.W. Chang: Starch depletion and sugars in developing cotton leaves. Plant Physiol., 65, 844-847 (1980).

14) Y. Takeda, K. Shirasaka and S. Hizukuri: Examination of the purity and structure of amylose by gel-permeation chromatography. Carbohydr. Res., 132, 83-92 (1984).

15) Y. Takeda: Structures of rice, maize and other plant starches. Denpun Kagaku, 40, 61-71 (1993).

16) K. Kitahara, J. Ueno, T. Suganuma, K. Ishiguro and O. Yamakawa: Physicochemical properties of root starches from new types of sweetpotato. J. Appl. Glycosci., 46, 391-397 (1999).

\section{サツマイモの葉における同化デンプンの 分子構造変化}

北原兼文，内野孝之，沖園一陽，菅沼俊彦 鹿児島大学農学部生物資源化学科 （890-0065 鹿児島市郡元 1-21-24）

3 力月間栽培したサツマイモの葉を時間ごとに 2 日間に 渡って採取し，含まれるデンプンの構造を調べた。葉の デンプン含量は, 夜明け前 5 時を最小, 夕方 5 時を最大 とする概日リズムが認められた (Fig. 1). 葉のデンプン は，組織を熱ジメチルスルホキシド中で摩砕することに より抽出し，ヨウ素により特異的に沈澱させて調製した. デンプンとアミロペクチンのトヨーパール HW-75F ゲル 濾過分析により，葉のデンプンは，塊根のものに比べて， 低分子側の溶出量が多く, この低分子画分には, アミ ロースと多量の低分子アミロペクチンが存在することが 明らかになった（Figs. 2，3）。 また，葉のデンプンとアミ ロペクチンの分子量分布は，いずれも昼間に高分子側に 移行し，日没から明け方にかけて低分子側に移行した (Fig. 3).さらに，枝きりしたデンプンとアミロペクチン の鎖長分布と短鎖分布を，それぞれ高速液体ゲル濾過ク ロマトと高性能陰イオン交換クロマトにより分析した。 葉のデンプンの鎖長分布は，塊根のものと明らかに異 なっていた（Figs. 4，5）。デンプンとアミロペクチンの鎖 長分布における長鎖画分の差として評価したアミロース 含量は，昼間が低く（Table 1)，一方，主にアミロペクチ ンを構成する短鎖分布は，昼夜における変動がほとんど 認められなかった（Fig. 5)。このように，サッマイモの 葉の同化デンプンについて，構造上の特徴と，その昼夜 における変化を明らかにした。 